\title{
Multilingualism and the language education landscape: challenges for teacher training in Europe
}

Gudrun Ziegler

Correspondence:

zieglergudrun@gmail.com

DICA-lab, University of Luxembourg,

Luxembourg L-2721, Luxembourg

\begin{abstract}
Europe is at the forefront of the development of policies that promote multilingualism in its member states, both on the social and the institutional level, as well as plurilingualism on the individual level. As Europe faces the challenge of multilingual education and diversity on various and exceedingly heterogeneous levels with regard to plurilinguals' realities, stakeholders and key decision-makers have developed visions of the situation of language teacher education and its structures. This paper presents these visions and provides insights from a recent critical evaluation of the policy instrument "European profile for language teacher education" (first published in 2004). Based on the study results obtained from a hundred decision-makers and language teacher trainers who participated in a European study on language teacher education, we discuss their perspectives relative to the current training infrastructure available in Europe. This study highlights key problematic issues, especially in light of the increasingly diverse student bodies, and highlights potential solutions for the European language context.
\end{abstract}

Keywords: Language teacher education, Language policy, Europe, Multilingualism, Plurilingual education, Common framework, Professionalisation 


\begin{abstract}
L'Europe est connue pour sa politique qui promeut le multilinguisme sur différents plans, éducatif et professionnel. Cette étude présente les résultats d'une enquête critique récente qui interroge l'apport d'un instrument politico-éducatif intitulé "Profil européen pour la formation des enseignants de langues étrangères", publié en 2004. Partant des résultats obtenus auprès d'une centaine de décideurs et de formateurs d'enseignants de langue, l'étude discute de leurs perspectives et visions face à la situation actuelle et des structures de formation d'enseignants de langue en Europe en place. Les objectifs d'une éducation face à la diversité et I'hétérogénéité croissante parmi les élèves se trouvent au centre des questionnements. Les résultats de l'étude indiquent les domaines à fort potentiel de risque pour l'éducation plurilingue. Les conséquences des résultats de l'enquête ainsi que les solutions possibles sont présentées en prenant l'Europe multilingue comme exemple.
\end{abstract}

\title{
Introduction
}

Multilingualism and multiculturalism are functional realities in today's European societies. These realities challenge traditional visions of language education, where each language is taught one after another as first and successive foreign languages. However, advances to promote multilingualism in and through this one-language teaching paradigm face resistance due to contradictions at different levels, which this paper discusses in detail below. One important contradiction concerns the individual language-teaching professional who supposedly works in favour of multilingualism, yet, has usually been trained as a specialist in one language.

Drawing both on socio-cultural (Lave \& Wenger 1991, Vygotsky 1978) as well as socio-educational perspectives, the present paper discusses a study that was conducted with language teaching specialists and stakeholders in the area of language teacher training across Europe. The results highlight a need for the development of a framework by defining the grounds, implications, and aims of a language teacher (education) in and for an advocated multilingual Europe.

The results of the study also show an imminent need for identifying the changing identities of the language teacher in multilingual realities (Singh \& Richards 2006) and review the said necessity to create consistency throughout Europe in developing and professionalizing teachers of languages as agents of multilingualism. This paper builds on the concept of "professionalizing" as attempting to gain a sense of "self" when developing as a professional language teacher. Multilingualism is shown to have a key influence on the language teaching professional though the practice of it often contradicts established practices. Specifically, the case of young professionals and language teacher trainees, who have been facing established "one-language-one-teacher" paradigms during their school experience in a particular national or generational setting, highlights the on-going need for change in the field of training language professionals as agents of multilingualism.

Based on the results of the study, this paper suggests that the construction of a methodological and conceptual foundation, with multilingualism at its center, is necessary in order to identify the field to which a language teacher will need to assimilate to as a 
professional. The development of practices that will guide the creation of a community of language teaching professionals who go beyond monolingual language training and educational structures is an important issue, especially with the goal of defining a complementary pedagogical approach for a multilingual Europe. The distinction made by the Council of Europe between a collective or social dimension of "multilingualism" and the individual's dimension of "plurilingualism" as "plurilingual repertoire" is particularly challenging when it comes to educational implications for teacher education and the varying realities of languages and diversity of population in the different European contexts (cf. http://www.coe.int/t/dg4/linguistic/division_fr.asp).

\section{Background of the study: multilingualism as a critical issue in language teacher educa- tion of the 21 st century}

Language teachers have been given a special position relative to teachers of other subjects. A language is presented as being the reified object of teaching (e.g., vocabulary or grammar). Moreover, language practices especially in classrooms, raise intercultural and power issues, which often appear when human artefacts or symbolic tools such as language are put to use (Blyth 1997, Faraco 2006, de Haan and Elbers 2009).

Arguing that teachers of language and their working contexts in the classroom are different from that of other subjects, we consider their global role along two axes. Firstly, the language teacher represents the language under study as well as other related elements. For instance, the French language teacher in certain contexts might be associated not only with the language but also with specific elements related with current political or historical issues of France. Secondly, the language teacher is interacting in a particular, situated, classroom setting that might evoke his/her age, hobbies and other dimensions that come up in classroom communication and interaction. The language teacher is thus also approaching language as a mediating tool for communication and acting in the language, which is then no longer, and not exclusively, an object of teaching but a means of interaction.

Multilingualism represents a challenging issue for current schooling contexts and language teachers are often considered to be intuitive main actors in this area, promoting and integrating multilingualism. Accordingly, the two aforementioned role-domains of the language teachers are critical when assessing how they will carry out their intuitively or politically defined roles as agents of multilingualism in Europe. Firstly, the professional identity of language teachers generally emerges from training as a language teaching professional, but in one language only. A potential professional identity of the one-language teacher evolving into one of multilingualism (i.e. to represent not only the one language of teaching but several languages and their interaction in general) is currently a challenge for him or her. A second challenge of multilingualism arises in interaction with learners who are both learners of the language classroom and also plurilingual individuals with their respective linguistic biographies and practices from their language communities.

At the beginning of the 21st century, these issues, which are situated at the intersection between Europe's proclaimed societal multilingualism and its plurilingual individuals, have been addressed in the report on the "European Profile for Language Teacher Education" (EPLTE) (Kelly and Grenfell 2004). The report responds to a call for a synoptic outline of 
the challenges of language teacher education in an increasingly multilingual, mobile, and technology-driven society, both within and beyond European borders. While the EPLTE has been largely disseminated, little information is available on the interpretation and understanding of the EPLTE, as regards to multilingualism and diversity of plurilingual repertoires in classrooms. We especially lack feedback from Europe's language teachers, relevant political stakeholders, and teacher educators. To address this issue, Ziegler et al. (2009a) conducted a study which brought together language teaching professionals, political stakeholders and players in the area of language teacher education around the EPLTE. Based on the findings and recommendations of this study, the current paper discusses core issues, focusing in particular on the importance of language teacher identities in professional, educational, and related policies in the face of multilingualism.

\section{Methods and participants of study: challenges of a common framework for language teacher education in multilingual Europe}

Europe's policies on plurilingual repertoires focus on the individual learners and their linguistic biographies through language portfolios, intercultural (auto-) biographies, and media literacies for gaining access to various languages (Byram 1997, Council of Europe 1997, Cope \& Kalantzis 2000, Zarate et al. 2008). However, language teachers, as major facilitators of language learning, are rarely in focus in the development of plurilingualism on a European scale. The European portfolio for language teacher education (Kelly and Grenfell 2004, Kelly 2009) points to the pivotal role of language teachers in this process in Europe. Specifically, the EPLTE (2004) stresses the fact that language teachers are in direct contact with the plurilingual learners and have to manage local contexts of multilingualism, diversity, and the relevance of a specific language in the local educational context. Therefore, the EPLTE provides a set of elements, which is meant to help individual European countries to act towards a more common language-teacher educational framework. Specifically, the EPLTE highlights the importance of a sustainable dissemination of a multilingual perspective of language teacher education across Europe and gives indications on how to strive for suitable implementations of a common multilingual framework of language-teacher education. However, suggested syllabi for language-teacher education show little awareness for this issue in terms of professionalization, specific preparation, and training of candidates across Europe. Furthermore, the pan-European concern of suitable language-teacher education in and for multilingualism needs to be concerned with context-sensitive implementations in a given national or regional environment. Hence, potential pitfalls of a common European perspective on syllabi of language teacher education have to be addressed, especially as the individual language teacher faces a training scheme geared towards the development of a professional vision of a teacher education in the light of multilingualism and plurilingual repertoires.

A group of stakeholders and language teacher educators $(\mathrm{N}=106)$ discussed the challenges of a common framework of language teacher education in Europe. 96\% (102) of the participants were from the EU, while 4\% (4) represented non-European institutions that deal with European languages. As depicted in Figure 1, 15\% (16) of the participants were policy makers at ministries or European institutions in the area of teacher 


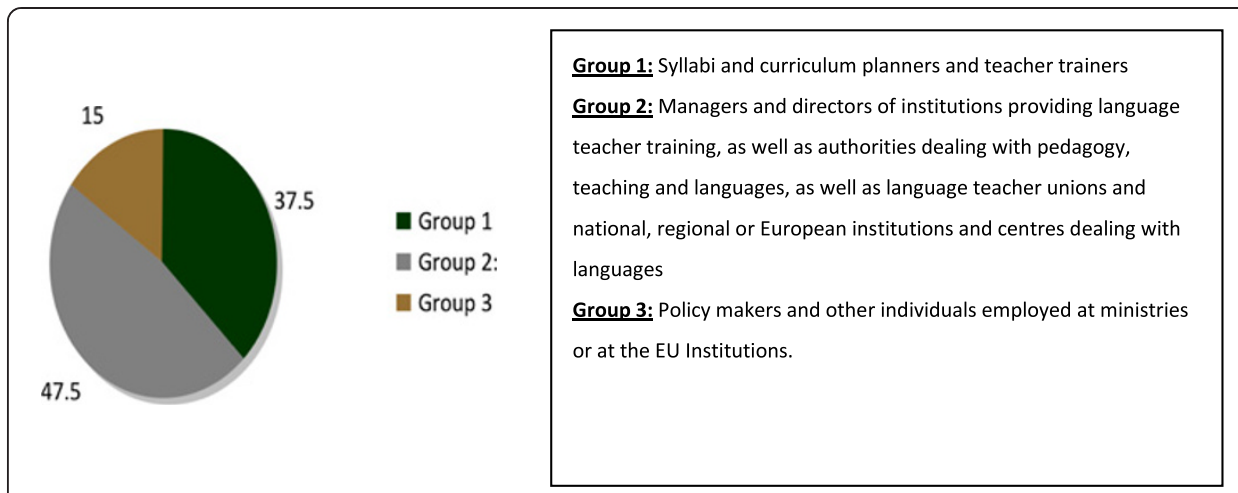

Figure 1 Participants in the study (adapted from Ziegler et al. 2009a).

education planning, 37.5\% (40) were syllabi/curriculum planners or teacher trainers and $47.5 \%$ (50) were managers, directors of institutions for teacher training, language pedagogy including teacher unions. Identifying a group of stakeholders and teacher educators as regards language teacher education in Europe requires careful assessment, given the heterogeneity of educational issues across Europe. Decisions are taken on different levels: certain groups of stakeholders play an important role in one national context and are barely visible in a neighbouring country. Therefore, the study identified a maximum of three participants per European country from three relevant areas of intervention in language teacher education; policy makers, language teacher educators, and directors of teacher training institutions. Other stakeholders (e.g., non language teaching areas which are also concerned by multilingualism such as general education or subject matters) were not included. The participants declared their interest and availability to participate in the study. The selection as well as the limited size of the sample of stakeholders shows the limitations of the study. Yet, given the complex situation of language teacher education across Europe (ethical approuval was provided by the project, http://semlang.eu), this study marked a first step in providing comprehensive, yet limited insights into the area.

In order to explore the visions and perspectives of participants relative to the current state of a common framework of language-teacher education in each participant's local context, the study (conducted in 2009) applied a mixed method approach, bringing together i) a first exploratory survey, ii) a second thematic survey and iii) focus-group interviews. The two surveys were open to all participants and were conducted anonymously by means of online questionnaires. The questionnaires were mainly composed of multiple-choice questions, providing free writing space for comments, insights from experience, and suggestions. Additionally, and in order to assess the often complex local situations of language-teacher education of the participants, four focus-group discussions were conducted. In line with the exploratory participant-bound perspective (Ziegler et al., 2009b, 6), the study was interested in the rating as done by the participants with regard to key topics and critical issues in a common framework for language teacher education (ii, second survey). A first survey allowed for stating if and to which extent participant stakeholders rank the issue of multilingualism in their context of language-teacher education. The focus group discussions centred around questions that arose from the survey (see Appendix) in order to better grasp the visions of the 
participants as expressed in the ranking according to relevance of a topic. The points raised and discussed in the focus group interviews help to put into perspective the quantified ranking of most critical issues in the context of a common framework of language teacher education in Europe.

\section{Finding 1: relevance of multilingualism in a common framework of language teacher} education

Participants indicate multilingualism as being a core element in language-teacher education, and in the life and work of a language teacher in Europe. In survey 1, when asked about the participants' awareness of multilingualism, 95\% (101) indicate that multilingualism is familiar to them as a concept and as a European effort, and that it therefore should ultimately be seen as an integral part of language teacher education (see Figure 2).

Interestingly, only $47 \%$ (50) of the respondents have actual experience in working with multilingual groups in their educational contexts. In the focus group interviews, participants raise four major concerns as regards multilingualism and a common framework of language-teacher education in Europe.

Firstly, they indicate that within their contexts (e.g., syllabi of language teacher education on a national level) the multilingual and multicultural aspect in language teacher training is given too little attention. The impact of multilingualism as experienced by pre- and inservice teacher trainees was raised as language teachers face various kinds of multilingualism and language varieties on the one hand and are in charge of the foreign language of the local syllabus on the other hand. Participants particularly pointed to the pre-service and in-service trainee contexts. In these contexts, the European vision of multilingualism meets local expectations, which trainee-teachers (and others) have as regards outcomes in a given foreign language. Yet, trainee-teachers face the reality of the challenges in line with plurilingual repertoires, which the heterogeneous student populations bring along. Current

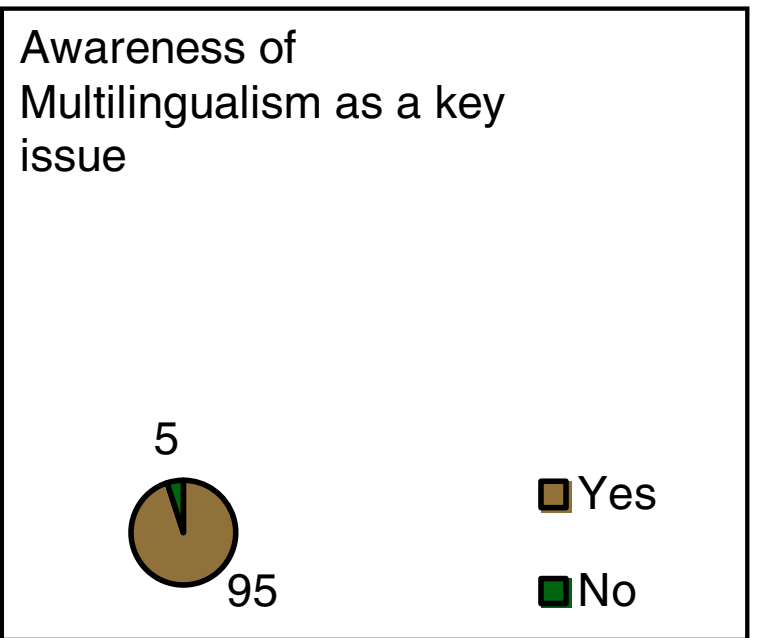

Figure 2 Multilingualism as a key element in language teacher education (adapted from Ziegler et. al. 2009a). 
language teacher education across Europe does not address possibilities for integrating multilingualism in pre- and in-service education of language teachers.

Secondly, stakeholders identified two pedagogical areas, which according to their visions are in line with the aims and issues of multilingualism in language-teacher education. Early foreign language teaching, as well as the ever more generalized use of Content and Language Integrated Learning (CLIL), are well known schemes amongst language teachers and language teacher education frameworks. However, these well known pedagogical approaches currently remain largely below their potential to work for the proclaimed European multilingualism. Teacher education frameworks seem to fail to embed these promoted approaches or to present the practical knowledge from these approaches in language-teacher education. Participants of the study highlight that a common framework of language teacher education should draw from such flagship approaches and experiences.

Thirdly, stakeholders in the area of language-teacher education point out that models and concepts of teaching languages from a multilingual perspective still lack concepts and theoretical underpinnings. Models, pedagogical instruments, and tools for evaluation in language teaching often contain visions of monolingual learning and idealisations, such as considering the "native" speaker of a language as the norm (cf. European language portfolio). Language teachers in particular are sensitive to these issues and their concerns of being a professional in a language need to be taken seriously, especially in light of the theoretical and practical implications of multilingualism. In the perspective of the participants of the study, many efforts on the European level are concerned with political visions and practical instruments but fail to address multilingualism as an individual reality of plurilingual repertoires and lifelong learning (e.g., language identities, transversal competences).

Finally, the issue of how a common framework of language teacher education can be applied to diverse contexts as a frame of reference is identified as a problematic domain. Participants argue that, content-wise, such a framework (e.g., EPLTE) runs the risk of being considered too general or even vague when addressing overall issues. Participants suggest a closer focus on transversal language competences and ways of conveying such integrated competences. Other areas under discussion include a focus on curricula integrated multiple languages, contrastive grammar, or devices for the learning of languages in a multilingual context.

In sum, perspectives of the stakeholders participating in this study show a need for better understanding the implications of multilingualism and plurilingual repertoires at a general level, but also to embed existing structures and practices in a larger, but locally valid picture, which recognizes the expertise - linguistic and pedagogical - of a language teacher within a given educational setting (Toohey and Waterstone 2004).

\section{Finding 2: core issues for language-teacher education facing diversity}

Following the various dimensions relevant for the conception of a common framework for language teacher education (Kelly and Grenfell 2004), participants of the study ranked a set of themes and topics according to their priority for the advancement of language teacher education facing multilingualism and related challenges. 
Participants' perspectives on the importance and the relevance of the topics were assessed by means of a thematic questionnaire in Survey 2 (see list of items below, Figure 3) and these provide interesting insights into the participants' lived reality of conceptual elements, institutional practices and hands-on implications of language teacher education according to their contexts. Therefore, it is of interest to state and to further investigate the ratings of importance of the topics as they show the perceived needs and pitfalls of a common framework for language teacher education and an

Rating of themes, relevant for language teacher education (6,0 highest rank, 1,0 lowest rank)

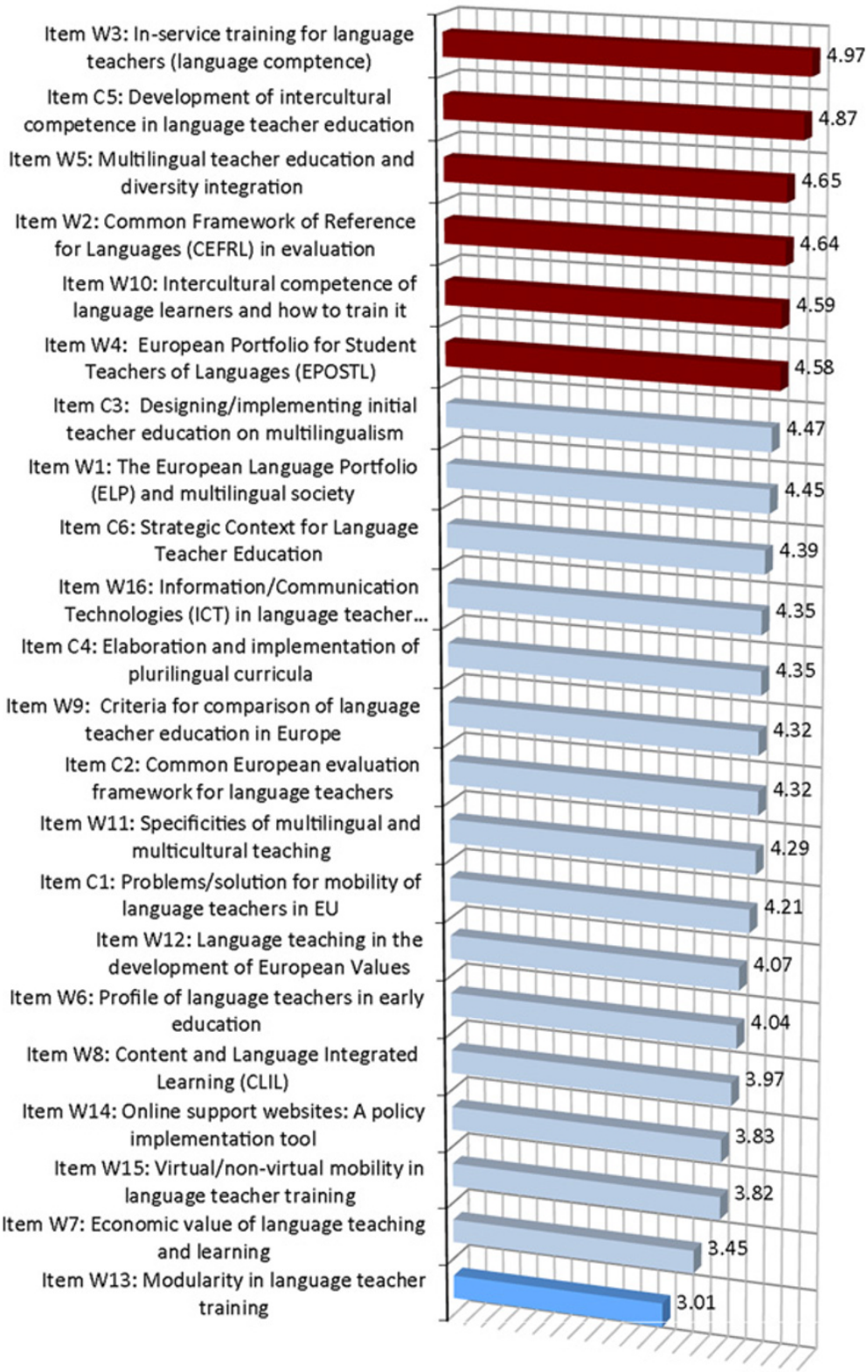

Figure 3 Rating of given topics for current situation of language teacher education (based on Ziegler et al. 2009a). 
instrument such as EPLTE (Kelly and Grenfell 2004). In fact, the participants' perspectives clearly identify the major issues in their reality impact.

Participants were asked to rate the themes according to their perceived importance, value 6 being very important, value 1 being of little importance. The following six themes scored highest (above rating 4,5) in the thematic survey. Figure 3 provides an overview:

1. The role of in-service training for language teachers in the domain of language competence (average rating: 4.97)

2. Incorporating the development of intercultural competence in language teacher education (average rating: 4.87)

3. Multilingual teacher education and diversity integration (average rating: 4.65)

4. Using the Common European Framework of Reference for Languages (CEFRL) in evaluation - challenges and opportunities (average rating: 4.64)

5. Intercultural competence of language learners and how to train it (average rating: 4.59)

6. The use of the European Portfolio for student teachers of languages (average rating: 4.58)

The results of this ranking were presented to the European agencies as regards the potential of a common framework for language teacher education (see Ziegler et al. 2009a). In this section, we critically discuss these results in the light of a suitable concept for the professional identity of a language-teaching expert facing multilingualism and plurilingual repertoires alike, both as a challenge and as an opportunity.

Firstly, the results illustrate that the highest rated topics concern major domains of improvement and areas of actions with regard to the ongoing development of the language teaching professional. Specifically, participants rank highest the key area in language-teacher education, which is the language taught in its larger implementation (rank 1). Similarly, they rank second the need felt for ongoing development in terms of cultural awareness and intercultural competence (rank 2) as well as its integration in core education and training. Both domains address the need for lifelong learning issues and intergenerational work as a major element in language teachers' professionalization and suitable adaption to the challenges of today. Moreover, these ratings point to the fact that these dimensions are relevant in the heterogeneous reality of language-teacher education and require attention from all key actors in this field. In line with these results, participants raise, in the focus group discussions, the issue that the development of teachers is often neglected: the actual multilingual practices of language teachers are not taken into account. Yet, the participants highlight that the assurance of their language teacher identity and professionalization consist in areas such as intercultural understanding and language competences at large.

Secondly, stakeholders are aware of the challenges and opportunities of today's educational landscape. In fact, the relevance of concepts and practices of multilingual education are highly rated which clearly shows its importance with regard to society's diversities and the management thereof (rank 3). Practices and the suitable integration of such into a non-fractured, European-bound language and general teacher education is a key concern. Moreover, opportunities of generalized frameworks are clearly welcomed by the participating stakeholders. They also state the problematic issue of 
knowledge evaluation. According to them, evaluation schemes are often inconsistent and go against a context-sensitive implementation of profile-bound tools for the evaluation of development. Specifically, participants point to the potential of the CEFRL, as it is exploited for suitable, lifelong learning-bound evaluation beyond profile-unspecific grids (rank 4). This dimension is closely related to the socio-economic value of language learning and therefore to the profession of language teaching.

Thirdly, the participants are concerned with language teaching using schemes with language learners of all ages in relation to cultural and intercultural issues. In fact, participants identify this need within the professionalizing structures, focusing on the impact of intercultural professional development (rank 5). This priority, then, together with the higher ranked priorities (ranks 1-4), show the importance of an adequate and integrated education in these respects for future professionals and student teachers. Participants also ranked available tools for integrated teacher education schemes, such as the European Portfolio for Student Teachers of Languages at the European level accordingly (rank 6).

In sum, the closely ranked issues (above value 4.8 for rank 1 and 2, above value 4.6 for rank 3 and 4, above value 4.5 for rank 5 and 6) show, however, a core domain (above value $4.8>$ above value 4.6, 4.5.) with regard to the actual identity and relevant professional development of a language teaching professional within the larger educational landscape and the professional development, as continued across structural limitations and areas.

This is also supported by the focus group interviews, where the identity of language teachers was discussed with regard to their intercultural competences, cultural awareness and their ability to include all students in class activities and the classroom community. Moreover, the participants indicated a need for a wholehearted recognition of the language teacher's occupation in order to ensure that a skilled individual undertakes language teaching. Interestingly, this trend resonates with the need for an increased focus on intercultural competences, diversity, and integration in a multilingual society as well as more context-sensitive, European-bound, frameworks aiding the continued development of language teaching professionals. In sum, participants point to the necessity to insure the recognition of the language-teaching professional as a skilled and lifelong-trained professional. This fact is reflected in the high rating of issues such as intercultural competence and general cultural awareness, an increased and timely focus on multilingualism, as well as digital literacy as primary issues needing increased attention in language-teacher education.

\section{Finding 3: language-teacher education: identity building for professionals of multilingualism}

The perspectives on multilingualism for language teacher education and the ranking of issues at stake in this respect (see above) and the topics developed in the focus group interviews provide further insights into the main weaknesses in current training and the needs identified by the participants. Areas highlighting interrelations relevant for the development of the language teaching professional in the era of multilingualism and everyday issues of diversity and technology were also identified (Ziegler et al. 2009a, 46). The domains as given below read as complementary polarities - such as 
identity building on the one hand and professionalization on the other hand - which language teachers and their educational schemes currently struggle to integrate. Several domains address structural issues which stakeholders deem necessary to be in place on the local as well as on the European level as a basis for further developing a common framework of language teacher education (e.g., in-service training in another country, cf. Ziegler et al. 2009a, 52). With regard to a coherent vision of the identity of language teacher in the face of multilingualism and diversity, the current paper discusses the following areas in more detail:

1) Identity vs. profession: Identifying the language-teaching professional

2) Knowledge vs. values: Multilingual language education across borders and grids

3) Multilingualism vs. Languages: Conceptual and practical needs

These complementary polarities (domains 1-3) are synthesized in line with the issues raised in the focus group interviews. The synthesis indicates the interconnectedness as well as hierarchical and structural overlaps and contradictions, which the individual language-teacher-actor is facing in general at any given point in his/her career today.

\section{Identity vs. profession: Identifying the language-teaching professional}

Instruments like the European Profile of Language Teacher Education and concepts of a common framework of language teacher education entail discussing the identity of a language teacher. The profession and professionalization of a language teaching professional is not only linked to the knowledge and understanding, strategies or skills or even values that such an individual possesses or displays in action (House and Rehbein 2004; Maulini and Montandon 2005). Rather, participating stakeholders discuss what characterizes such an individual and how this can be instigated through institutional support and evaluated in a suitable, context-relevant fashion.

“...was mir wichtig scheint ist zu überlegen was ist denn das was das

Fremdsprachenlehrerdasein, ob Französisch, ob Deutsch als Fremdsprache, ob Englisch, ob Russisch auszeichnet, was müssen die sozusagen über diese allgemeindidaktischen pädagogischen Dinge hinaus können, was ist das Profil von den Leuten ..." (Focus group, D-1)

(Translation author: What seems important to consider, from my perspective, is what constitutes the being-a-language-teacher, be that in French, German as a foreign language, English or even Russian. What do these individuals need to master beyond the general didactical pedagogical techniques.... what is their profile?)

Participants stated that a language teacher is marked by a desire or "... a certain charisma, perhaps" (Focus group, E-1) to be able to motivate students, create a learning environment as well as an ability to adapt teaching approaches to the educational context and individual needs of the learner (cf., Kelly and Grenfell 2004, point 22). The identity of a language teacher is different from that of another teacher, though participants highlighted the fact that every teacher is in a way a language teacher (Byram 2003; Byram and Feng 2004). The teacher needs structural support, training towards knowledge in specific areas, to be taught how to master skills and strategies and realize 
the importance of certain values; but he/she also needs to have a willingness to do so, to engage in professional development, to want to learn from the learners, and to consistently undergo an evaluation of his or her own approach towards the students.

"Sometimes [as] teachers, we do not consider that [we] are part of an interaction which is an asymmetric interaction and that [we behave according to patterns of interaction that are part of their culture. Sometimes these patterns are correct [...] but most often they are not, which is why it's important to be the student at times. I'm sure a period of going back to the classroom as students is also important for us." (Focus group, E-2)

Also, the language teacher is - with regard to the recent European past and also as regards the continuing integration of new member states - seen as a major actor in bringing about change and managing the diversity of today's societies.

The participants in the focus groups as presented in Figure 4 highlighted the fact that a more tangible definition of the language teacher was needed. The analysis of the focus group interviews reveals the use of more descriptive adjectives in trying to characterize the individual language teacher. Other contributions try to explain their understanding in more structure-system oriented ways, and yet other comments offer metaphors. What is interesting to note is that the three focus group set-ups (French-speaking, German-speaking and English-speaking) refer differently to the issues raised throughout the focus groups, which can serve as an indicator for the need of the development of a shared vision and, as a first step, a common language on the matter (Allen \& Negueruela-Azarola, 2010; Byram and Feng 2004). For instance, the general adjectives came from the English-speaking focus group, the structural system-oriented from the German-speaking, and the metaphorical from the French-speaking focus group.

\begin{tabular}{|c|c|c|c|}
\hline & \multicolumn{3}{|c|}{ Focus group interview conducted in } \\
\hline & German (translation GZ) & English & $\begin{array}{l}\text { French (translation } \\
\text { GZ) }\end{array}$ \\
\hline 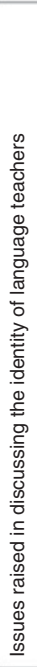 & $\begin{array}{l}\text { - Identity Question is a } \\
\text { question } \\
\text { professionalism of } \\
\text { - It appears that the } \\
\text { (academic) } \\
\text { requirements for } \\
\text { becoming a language } \\
\text { teacher are different } \\
\text { than those of becoming } \\
\text { e.g. a physics teacher } \\
\text { - Today, anyone native } \\
\text { in a language can } \\
\text { become a langue } \\
\text { teacher. One needs a } \\
\text { system of sorts to } \\
\text { prevent that and ensure } \\
\text { quality neds to develop } \\
\text { - One needs } \\
\text { a common basis with } \\
\text { other language } \\
\text { teachers in the } \\
\text { department, in the } \\
\text { country from where one } \\
\text { can share and } \\
\text { exchange best } \\
\text { practises and and } \\
\text { experiences }\end{array}$ & $\begin{array}{l}\text { - Open mind } \\
\text { - Flexibility and } \\
\text { adaptability } \\
\text { - Creativity } \\
\text { - Charisma } \\
\text { - Willingness to explore } \\
\text { together with students }\end{array}$ & $\begin{array}{l}\text { - There's lots of } \\
\text { research currently } \\
\text { being done in the } \\
\text { field, complexity of } \\
\text { identity because of } \\
\text { the cultural } \\
\text { dimension language } \\
\text { - How } \text { How lacher envisage } \\
\text { teachel } \\
\text { themselves in other } \\
\text { relation to } \\
\text { teachers } \\
\text { - Publication on the } \\
\text { matter, dealing with } \\
\text { that exact issue } \\
\text { - I think, one is asking } \\
\text { too much of the } \\
\text { language teacher, } \\
\text { maybe even too } \\
\text { much for her to } \\
\text { manage in the time } \\
\text { allocated (in relation } \\
\text { to other teachers) } \\
\text { - A langue teacher is } \\
\text { like a door, a } \\
\text { window, to the } \\
\text { outside, a different } \\
\text { world, a different } \\
\text { society }\end{array}$ \\
\hline
\end{tabular}

Figure 4 Overview of issues raised in focus groups on the discussion of the identity of the language teacher (developed from Ziegler et al. 2009a, 2009b). 
Although there were several nationalities in the groups, mostly using the language at hand as a foreign language, the similarities in the wording of the issues as regards language-teacher identity were surprising. The summarized table (Figure 4) provides an overview of the items used in each one of the focus groups.

Knowledge vs. Values: multilingual language education across borders and grids

"I think there are several ways of collaboration... we can have projects, international projects... where... groups or groups of teachers form different contexts...they gather around a problem a common situation .... and then they devise solutions for their different context but within common principles..." (Focus group, E-3)

In Survey 1, it was found that 60\% (64) of the participants acknowledged they had some experience with intercultural learning, while 65\% (69) had an understanding of intercultural teaching. 95\% (101) were familiar with multilingualism (as a concept) and $68 \%$ (72) of those were also familiar with the concept of European citizenship. Nevertheless, only $47 \%$ (50) had experience in teaching multilingual groups. In terms of changes needed to language teacher education in their home countries, 19\% (20) argued that the most important were aspects such as teaching respecting plurilingual repertoires, intercultural awareness or even European citizenship. Specifically, 29\% (31) of the participants argued that multilingual and multicultural aspects need to be integrated, either as an element during teacher education, or as a value that the trainee teachers should know how to promote and teach themselves. This is in line with a European vision of citizenship as promoted by the European Profile of Language Teacher Education (Kelly and Grenfell 2004, 42): "European citizenship corresponds to a set of shared values and beliefs in democracy, the rule of law, the free press and a shared cultural heritage". Despite these statements and identified needs in this area of European language teaching, participants agree that little is available about the content of these European values.

Given this highlighted and identified necessity, the enormous efforts in evaluation along grids of "knowledge" and not of values is perceived as a major challenge for language teaching professionals, as they wish to provide sustainable work in line with the European aims. Yet, these initiatives (e.g., actual work on the creation of European-bound perspectives and values) are poorly rewarded by otherwise content-driven evaluation-only schemes. One group of participants framed this as a paradox, which they summarized as "getting rid of the grids", as these seldom allow for including both contents and values in the teacher's work. At the same time, the wish for standards and common goals for the profession and suitable outcomes (e.g., multilingual learning) is clearly stated.

\section{Multilingualism vs. Languages: conceptual and practical needs}

In regards to the pressing contradiction between plurilingualism as a mode of living on the one hand (cf. Grosjean 1984; Grosjean 2010) and languages as separately taught entities in educational contexts, participants illustrate the fact that multilingualism is highly available in discourses but is still in its infancy from a methodological and applied viewpoint. For instance, language teachers have to be ready to develop practices that aim at dealing with multilingualism and plurilingualism on multiple levels (e.g., syllabi policies, individual learners) and to various degrees (e.g., develop a general 
understanding, develop specific techniques for dealing with multilingual literacies). Language teachers faced with the challenge of multilingualism and plurilingual repertoires can no longer draw on single resources like bringing in materials in a given language or from experienced multilingual practices (e.g., Erasmus exchange) (Goodman 2009). More than in the past, language teachers have to integrate language resources of multiple kinds, often available from the learners themselves - on site (e.g., classroom community), in parallel (e.g., videogames, music videos) and in a continued active form (e.g., languages used in play).

In fact, the participating stakeholders state that multilingualism has become a core topic in many contexts of policy making and the planning of teacher education (see above, survey 1). However, the focus group interviews address the need for empirically grounded, rather than model driven or policy driven, approaches towards multilingualism as a reality in today's societies. Specifically, multilingualism has, up until now, largely been dealt with in terms of different languages and how to master or teach them. Discussions have been focusing to a lesser extent on how to deal with multilingualism, plurilingual individuals, and languages in their cultural realities per se. That is, multilingualism has often been used in the context of immigrant issues or minority languages, where the individual speaker is expected to assimilate other languages in order to fulfill some societal, or even social, expectations. More recently however, the terms multilingualism and plurilingualism have become denominators in EU language policies, as the EU strives to become a multilingual community with the aim to reap the benefits of such rich linguistic and cultural resources (Group of intellectuals for intercultural dialogue, 2008).

Participants point out that plurilingual people (here, learners) often attribute different functions to their languages. These functional attributes however have little to do with linguistic diversity, or being able to speak many languages. Plurilingualism rather often involves identity issues, social perspectives on professional development and success. In this respect, there is pressing need to enable professionals to implement, exploit and foster multilingualism and plurilingualism at both the conceptual and practical levels (Byrnes 2009; Crookes 1997, Jessner 2008). Concomitantly, when a language teacher deals with individuals, who face multilingualism at different levels - something that has become common even beyond the European context - he or she does not only have to teach the language for the learner to be able to use the language, but needs to pay increasingly close attention to the various dimensions (e.g. functional, identity, social). The language will resonate differently for any given individual and at different moments across the lifespan (e.g., one out of two or more family languages, languages of higher educational success, languages of tourism). Regarding pre- and in-service teacher training, a multilingual environment will challenge the trainee teacher and require him or her to develop a certain stance towards multilingualism in its most tangible forms. He or she will train to teach one language as an entity and to teach within a framework with multifaceted plurilingualism. Participants highlight the need for the construction of a methodological and conceptual basis for dealing with multilingualism at its core. Otherwise, debates on how to make teacher education in Europe more multilingual, in any one of the two perspectives of multilingualism and plurilingualism, will fail to respect the fact that the language teacher is to act as a primary agent and placed at the centre of multilingualism and education. 
Strikingly, these issues - such as the value of language teaching - have still not found their way as key values or topics in the European educational landscape, let alone in language teacher education, which functions as a magnifying glass for the issue at hand. This is - as the following compilation shows - a major concern for the profession of language teaching, the training of young researchers and potential language students. Specifically, participants state "not to know enough about multilingualism and diversity" and to "lack examples of good practices" that show how to "handle multilingual contexts not only as problem" but to see "intercultural education as an advantage" (data Ch-1). Moreover, they highlight the fact that the "integration of diversity in various fields of work, research, and teaching should be promoted" on the level of "group work and the management of learning processes" by working in line with the value of diversity, multilingualism and plurilingualism (data Ch-2).

The results show that some initiatives that attempt to deal with languages as having a functional effect are beginning to appear, delineating a move away from language teaching for the sole purpose of interpersonal communication. From a language teaching perspective, CLIL (Content and Language Integrated Learning) was highlighted by many participants in the focus groups as a method that ensures that languages were not taught just for the sake of the language, but rather as tools for serving functional purposes (e.g., learning science in French, or learning maths in German) and thereby promoting the language from an early age. The identity of the language teacher as the language expert, however, was considered to be jeopardized in regards to CLIL practices. However, methods such as CLIL are currently not an integral part of a potential common framework of language teacher education.

Finally, the issue of ICT and the digital divide between learners and language teachers is an issue that sheds light on multilingualism in the literacy and language practices of today (Max 2011). Participants pointed out that learners often are active beyond the onelanguage entity, acting within a multilingual digital mode on an often daily and/or community basis (e.g., social media) to which language teachers have only limited access.

A summary of the issues put forth by the participants provides the following picture of the discussion of the professional teacher's identity and the values related to language education and multilingualism as an encompassing reality. As indicated in Figure 5, the issue

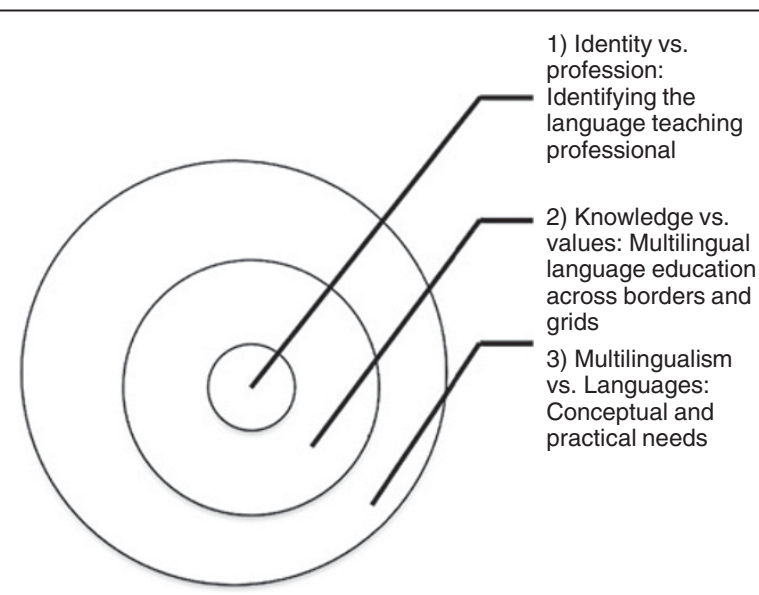

Figure $\mathbf{5}$ Language teacher identity at the centre of language teacher education facing multilingualism. 
of the nature of the identity of language teacher (1) in terms of expertise in a language, related pedagogical issues, societal multilingualism and individuals' plurilingualism is embedded in the definition of values defined for education today. In fact, the issue of decontextualised standards per individual language (2) is crucial as they are poorly responding to (3) multilingualism as a reality of biographies, communities, and various levels of literacies.

The findings highlight three issues that concern a potential common framework of language teacher education (Ziegler et al. 2009a, 58-59): the issue of being a professional European language teacher at the individual identity level; the ever growing need for more coherent professionalization at the individual's professional level, and the growing concentration on multilingualism and languages which poses needs for clarification in any given socio-cultural and socio-educational context at a societal as well as institutional level.

\section{Discussion: building language teacher identities in face of multilingualism}

The results of the participating stakeholders' views on challenges of language teacher education in the face of multilingualism and plurilingualism point to the larger area of roles and values, critical for language teaching professionals. The importance of selfrepresentation among professionals in education, as opposed to other professions, has been discussed as regards choice of professions (Antonek et al. 1997; Crookes 1997; Daniels et al. 2010). For instance, previous studies highlight the reasons for choosing a language as a teaching subject over other schooling subjects (Markee 1997; Singh \& Richards 2006). The findings of the current study however addresses the issue of what the profession of a "language teacher" means in the educational as well as societal landscape today by focusing on two issues in particular:

- The ongoing development of common frameworks for education in general and language-teacher education in light of diversities of societies in particular (cf. Kelly and Grenfell 2004).

- More importantly, as revealed by the current findings, the multifaceted realities of multilingualism as an aim (e.g., language to be taught) and as a challenge (e.g., language resources by the learners to be integrated) in the language-teaching profession today.

This study then points to the bi-focused underpinning of the language teaching profession which addresses the language teacher as the subject teacher in the schooling framework on the one hand and as an agent to bring about change and managing the multilingual and multicultural diversity of the classroom on the other hand. The gap between these tasks of the language teacher, which has been voiced by the participants of this study in terms of a call for reconsidering the very definition of the professional identities of the language teaching professional, shows the need for a deeper focus on "how language teaching professionals think about and perform language teaching" (Markee 1997, 80) in the face of changing societal realities. These changes challenge and often contradict the methodological guidelines currently in place. This is of particular relevance for language-teacher education schemes on the local and national levels, and more importantly, as regards initiatives for common frameworks, which 
ideally should act as a resource for dealing with societal realities beyond the local context (e.g., migration, professional mobility).

Participants in this study, who as stakeholders in the area of language teacher education assess and plan the teacher education schemes of the future both in the light of common frameworks as well as local needs, bring up the missing element in the current debates. This element is the identity of the profession of the language teacher to which in-service and pre-service teachers would comply. The results highlight the lack of a thorough analysis of the meaning of language teaching in the current educational arena. Available matrices of professional identity constructions address various domains (Kumaravadivelu 2009). For instance, language teaching methods and general methodological orientations serve as identity matrices when professionals comply with or reject specific methodological elements for their professional self-representation (Kumaravadivelu 2009). Participants in this study specifically highlight popular definitions of the past, which orient towards the language teacher as an applied linguist, a literature-person, or a person driven by the motivation to promote foreign cultures. Also, the very definition of language and the language selected by the professional to be taught often implies elements of professional identity by an individual teacher (e.g., teaching a language for the purpose of promoting cultural awareness). A specific, and voiced, understanding of grammar and acquisitional processes, which entail related teaching schemes, has served the purpose of indicating professional identity (Klein \& Perdue 1992). Moreover, a certain vision of language learners, their identities and the constructions of such inside and outside the classroom, inside or outside of testing schemes work as relevant planes for defining professional identities (Kasper 2004; Seedhouse 2004; Ziegler 2008). The present study then points out that little, if any, matrices are available which would allow for identity-building of the language teacher in the multilingual scene today, especially in Europe. More precisely, the participants of this study labelled this gap and the missing planes for identification by opposing "languages" (Cuq 2009, 27) which refers to a somewhat insufficient ideal of a languageand-culture-expert and "multilingualism" which refers to a somewhat unspecific vision of encompassing languages within education at large, across the life-span and across the various domains of living.

Following the indications given by the stakeholders participating in this study, the findings allow for the following - open - conclusions, which address indications of language teacher education and the definition of this very educational process, labelled here as "professionalization" in terms of professional identity starting with pre-service training in a lifelong learning perspective.

\section{Conclusions}

Plurilingual education perspectives in multilingual Europe

Firstly, language-teacher education acting to build professional identities should address tensions with regard to multilingualism and plurilingual repertoires as discussed above. Specifically, the struggle for building language teachers' identities should be framed as a consequence of the two ways conceiving of the "the language teacher". Pre-service and in-service teachers alike should be aware of the idealisations of not solely linguistic "homogeneity" within an individual European country, which often limits training to 
the "one-language-teacher". These idealisations, which take for granted a "prototypical communicative exchange" of "two or three interlocutors, who all conduct the interaction in the same standard target language, all agree on what the purpose of the exchange is and what constitutes a culturally appropriate topic of conversation, all have equal speaking rights and opportunities" (Kramsch \& Whiteside 2008, 645), need to be reframed. Bi-, tri-, and multilingualism, as enacted in school, require the individual teacher to construct interaction through a multilingual perspective. This however, raises the issue of "multilingual competence" with regard to "plurilingual repertoires" within and beyond linguistic competence in a language. In fact, the findings of this study of the European context highlight the worrisome gap between the politically advocated multilingualism on the one hand and the still poorly managed realities of plurilingual repertoires which often lead to a poorly monitored "English only" practice despite available linguistic resources. The findings, therefore, point to the need to model, analyse, and develop schemes for plurilingual education with a specific focus on language teacher education, responding to the shortcomings discussed. A concept of plurilingual education with regard to teacher education should therefore highlight the importance of developing multilingual competences considering that "le plurilinguisme n'est pas, comme le bilinguisme, conçu comme une adition de monolinguismes mais comme une compétence particulière" (Cuq 2009, 15). This competence has been present in the research literature with different labels: communicative competence (Hymes 1972), interactional competence (Kramsch 1986), or symbolic competence (Kramsch \& Whiteside 2008, 664). Symbolic competence includes linguistic competences and follows a definition, which puts the creation of a plurilingual in language teaching at the centre. Specifically, the language teacher within such a symbolic competence promotes "the ability not only to approximate or appropriate for oneself someone else's language, but to shape the very context in which the language is learned and used" (Kramsch \& Whiteside 2008, 664). A specific feature of a language teacher would then be to have a specific understanding of the various resources, which one speaker refers to when engaging in talk and interaction. The teacher would have a special lens for being sensible to issues of identity (cf. reference to a specific community or context of speaking) as enacted through language in a multilingual interaction. School, then, "as a social event" and "language as a social event" (Andrews 2006, 53), would take into account the way learners' identities are expressed through plurilingual resources and languages. In that respect, participants in language teaching are addressed as agents who resituate, "inhabit" (Durus 2009), and "rehistorizise" (Kramsch \& Whiteside 2008, 667) the resources, which are available to them at any given moment in time.

\section{Language-teacher education as acting for change}

Language-teacher education supporting the building of language-teacher identities beyond the "one language" tradition addresses language teachers in particular as agents of change in the societies of the 21st century. Whereas teachers were previously conceived of as external agents in a linear and hierarchical track, moving from educational policies down to the classroom and the individual learner via the teacher, a more suitable framework takes into account the individuals and the contexts as agents. 
Specifically, language teachers and their education as professionals would focus on the factors, which "influence how change actually occurs in language education" (Markee 1997, 90). The syllabi of language teacher education would then move away from contents and methods but focus on the context-bound question of "Who adopts what, where, when, why, and how?" (Markee 1997, 82).

On the level of the "individual," we therefore speak about language teachers who "may act as change agents, clients, adopters (or resisters), implementers, or suppliers of innovations" ultimately acting as agents of change within their classroom setting or school, but also externally with regard to home contexts and the integration of various resources, even including contradictions (cf. Markee 1997). This conception of language teachers as agents of change not only understand and integrate the dynamics and complexity of social identities and roles within interaction but they also sustain interests and, specifically, the interest of the teaching of a language with and for the learners. From the perspective of the individual, we are able to separate the elements of a process that was previously in a limited vision of "teaching" and to see both the topdown and the bottom-up infrastructural movements in terms of individual actors that are able to situate themselves in a multi-party process. In this line, we should consider "moving from a training perspective to a professional development perspective and substantiating this change with new practices that address foreign language graduate students' long-term needs as teachers and scholars" (Allen \& Negueruela-Azarola 2010, 377). Following the findings of this study, then, a language teacher "not only needs structural support and possibilities, training toward acquiring understanding or knowledge in specific areas, being taught to master skills and strategies to realize the importance of certain values, but also willingness to engage in professional development, to learn from the learners" (Ziegler et al. 2009a, 8) and to undergo a constant assessment of his or her approaches in the light of the actual situation constructed with the learners. Instead of conceiving of the language teacher as a second order agent, language-teacher education would address the issue of change and innovation as a matter of fact in language education, done on a moment by moment basis induced by the teacher on awareness of his/her professional identity as a language teacher working towards plurilingual education rather than merely facing diversity and multilingualism.

\section{Language teaching and plurilingual education}

Language-teacher education largely fails to integrate in a sustainable and tangible way, for trainers and trainees, the issue of language teaching as plurilingual education in general. This has massive implications for the professional identity of language teachers, because disciplinary delimitations (e.g. the delimitations between two languages) are a heavy burden. Working towards an understanding of language teacher education as building a professional identity that encompasses language and plurilingual repertoires as a general (i.e., essential) educational feature, which integrate various subjects and elements (e.g., media) beyond disciplinary fractions. In fact, realities of the lives of the learners may serve as a guidebook for developing such an integrated or plurilingual vision of language education and the professional identity for the language teacher in line with this attempt. Various research efforts point in this 
direction, involving school-level initiatives developed to support language teacher education from an educationally integrated perspective. Most of these initiatives address the "across-discipline" or "language-transversal" perspective despite the fact that interestingly - plurilingual initiatives on the level of language teacher education are still an exception (see for instance: The Teacher Development Model for Sustainable Education Reform (TDMSER) (Wilhelm 1997, 520), Career in Teaching program (CIT), Peer Assistance and Review (Crookes 1997, 71), Languages Across the Curriculum (Byrnes 2009), Student teacher portfolio (Antonek et al. 1997, 15) or CALL (Computer assisted language learning) (Zapata 2004, 339). Language teacher education then allows professionals to become participants in the construction of knowledge in line with local contexts, workplaces, and individual repertoires. Specifically, such an initiative would address the issue of building professional identities for the language teacher being educated with a perspective of multilingualism and larger and common frameworks for plurilingual education across Europe. With regards to previous education schemes, such a vision of language teacher education beyond disciplinary and medial divides would mark a step forward. This vision would then overcome many of the rather conservative factors in the currently existing trainings of language teachers in place at educational institutions. These institutions would then act as actual learning institutions and be "less like the static, time-defying forms" of education (Crookes 1997, 75).

The gaps in terms of disciplinary anchorage, generational segregation (cf. former points of reference in terms of being a language teacher), and also media divides in terms of media literacy are overcome by working towards suitable constructions of professional identities for language teachers. Such constructions operate across and beyond a one-language vision of the language teacher and bring about a multi-faceted but coherent vision of language teaching, which has multilingualism not only as an aim and a challenge but plurilingualism as a catalyst in and for education - of the learners and the teachers.

\section{Appendix}

Stimulus questions of focus group discussions, English version. One question per area $(1,2,3,4,5,6,7)$ was presented for discussion to the group.

1

- Is there an identity problem of "the language teacher"?

- Is s/he an expert of grammar, language, culture...?

- Is any teacher a language teacher?

- How about CLIL? Is CLIL in this respect a "danger" or an "open door" for "the language teacher"?

- What are the specificities of "the language professional"?

- How can s/he be trained with regard to these specificities?

2

- What is Europe's obligation in language teacher education?

- In which area do you think money is needed to do more investigation/research? 
- What do you think about organizing meetings of stakeholders across Europe?

- Who should be invited with regard to your local/national context?

4

- Do you feel overwhelmed, frustrated by all these elements language teacher have to be aware of / take care of? Multilingualism, Information technologies ... and other element as mentioned in the European framework for language teacher education?

5

- What does "Learning to learn" (as stated in the EPLTE) mean to you? Is this the business of a language teacher?

- What do you think about the "research attitude" as stated in the EPLTE?

- How do you rate/judge/understand the European Profile for language teacher education in general?

6

-Which are the biggest challenges/problems in language teacher education?

- Which are the biggest needs in language teacher education regarding your country and/or a particular level of schooling you are concerned with?

7

- Do you think it is possible to build a friendly relationship with trainee teachers and mentors today?

- How important is networking/collaboration/team teaching today, in your country? In Europe?

Competing interests

The authors declare that they have no competing interests.

\section{Authors' contributions}

The author was a co-contributor to the project, this study draws from and the investigator in charge of the scientific follow-up of the project, the analysis and the drafting of the results and subsequent discussion. All authors read and approved the final manuscript.

\section{Authors' information}

Gudrun Ziegler is an Associate Professor of Learning, Interaction and Multilingualism at the trilingual University of Luxembourg where she created and directed the Research Master - Learning and Development in Multilingual and Multicultural Contexts (2007-2011), a programme which figures on the list of innovative approaches for multilingual education by UNESCO, Institute for Lifelong Learning (Ziegler 2011a, 2011b). She received her PhDs from Sorbonne Nouvelle and Saarland University, specialising in language learning and interaction. Her international research projects focus on interaction, multilingual language development, teacher education in multilingual contexts, professional development in lingua franca contexts and the construction of disciplinary knowledge in multicultural and multimodal learning environments. She served as editor of ForumSprache, a multilingual journal on language learning and teaching (2008-2011), and has edited special issues on the construction of literacy in diverse contexts, language acquisition and professionalization of language professionals.

\section{Acknowledgments}

The findings discussed in this paper draw from results of the SEMLANG project, funded by the European Commission (http://www.semlang.eu/). The paper is presented with the support of multi-LEARN Institute for Interaction and Development in Diversity, Luxembourg and the DICA-lab research group, University of Luxembourg (http://dica-lab. org). We thank two anonymous reviewers for their insightful comments on earlier versions of this paper. 


\section{References}

Allen, HW, and E Negueruela-Azarola. 2010. The professional development of future professors of foreign languages: looking back, looking forward. Mod Lang J 94: 337-395.

Andrews, L. 2006. Language exploration and awareness. A resource book for teachers. New Jersey: Lawrence Erlbaum. Antonek, JL, DE McCormick, and R Donato. 1997. The student teacher portfolio as autobiography: developing a professional identity source. Mod Lang J 81: 15-27.

Blyth, C. 1997. A constructivist approach to grammar: teaching teachers to teach. Mod Lang J 81: 50-66.

Byram, M. 1997. Teaching and Assessing Intercultural Communicative Competence. Clevedon: Multilingual Matters.

Byram, M. 2003. Teacher education - visions from/in Europe. Babylonia 3-4: 7-10.

Byram, M, and A Feng. 2004. Culture and language learning: review article. Lang Teach 37: 149-168.

Byrnes, H. 2009. The role of foreign language departments in internationalizing the curriculum. Mod Lang J 93: 607-627.

Cope, B, and M Kalantzis (eds.). 2000. Multiliteracies: literacy learning and the design of social futures. London: Routledge.

Council of Europe. 1997. Plurilingual and pluricultural competence. Strasbourg: Council of Europe.

Crookes, G. 1997. What influences what and how second and foreign language teachers teach? Mod Lang J 81: 67-79.

Cuq, JP. 2009. Diversité culturelle, diversité linguistique ... vers une diversité métodologique pour les professeurs de langue? In Approches comparées de l'enseignement des langues et de la formation des enseignants, ed. C Gonçalves and D Groux, 99-11. Paris: L'Harmattan.

Daniels, H, A Edwards, Y Engeström, T Gallagher, and SR Ludbigsen (eds.). 2010. Activity theory in practice. Promoting learning across boundaries and agencies. London: Routledge.

de Haan, M, and E Elbers. 2009. From research to practice. What the study of multiethnic classrooms has to offer. In Social interactions in multicultural settings, ed. M César and K Kumpulainen, 171-202. Rotterdam: Sense.

Durus, N. 2009. Discourse strategies in learner inhabited talk. Scientific Master thesis, unpublished. University of Luxembourg.

Faraco, M (ed.). 2006. La classe de langue: Théorie, méthodes et pratiques. Aix-en-Provence: Presses universitaires de Provence.

Goodman, AE. 2009. Language learning and study abroad: the path to global citizenship. Mod Lang J 93: 607-627.

Grosjean, F. 1984. Life with two languages. An introduction to bilingualism. Harvard: Harvard University Press.

Grosjean, F. 2010. Bilingual. Life and reality. Harvard: Harvard University Press.

Group of intellectuals for intercultural dialogue. 2008. A rewarding challenge. How the multiplicity of languages could strengthen Europe. Brussels: European Commission. http://europa.eu/languages/en/document/106/5. Accessed 15 March 2012.

House, J, and J Rehbein. 2004. What is 'multilingual communication'? In Multilingual communication, ed. J House and J Rehbein, 89-102. Amsterdam: Benjamins.

Hymes, DH. 1972. On communicative competence. In Sociolinguistics: Selected Readings, ed. JB Pride and J Holmes, 269-293. Harmondsworth: Penguin.

Jessner, U. 2008. Multicompetence approaches to language proficiency development in multilingual education. In Encyclopedia of Language and Education, Volume 5: Bilingual Education, ed. J Cummins, 91-103. Amsterdam: Springer.

Kasper, G. 2004. Orientations in German conversation-for-learning. Mod Lang J 88: 551-567.

Kelly, M. 2009. Strategic contexts for the education of language teachers. http://europa.eu/languages/en/document/ 106/5. Accessed 15 March 2012.

Kelly, M, and M Grenfell. 2004. European Profile for Language Teacher Education (EPLTE). A frame of reference. Southampton: University of Southampton. http://ec.europa.eu/education/languages/pdf/doc477_en.pdf. Accessed 15 March 2012.

Klein, W, and C Perdue. 1992. Utterance structure. Developing grammars again. Amsterdam: Benjamins.

Kramsch, C. 1986. From language proficiency to interactional competence. Mod Lang J 70: 366-372.

Kramsch, C, and A Whiteside. 2008. Language ecology in multilingual settings. Towards a theory of symbolic competence. Appl Linguist 29: 645-671.

Kumaravadivelu, B. 2009. Understanding language teaching. From method to postmethod. New York: Routledge.

Lave, J, and E Wenger. 1991. Situated Learning. Legitimate peripheral participation. Cambridge: University of Cambridge Press.

Markee, N. 1997. Second language acquisition research: a resource for changing teachers' professional cultures? Mod Lang J 81: 80-93.

Maulini, O, and C Montandon (eds.). 2005. Les formes de l'éducation: variété et variation. Brussels: De Boeck.

Max, C. 2011. The development of initial teacher education focusing on multilingualisms: the innovative approach of Luxembourg. ForumSprache 5: 59-78. http://www.ingentaconnect.com/content/hueber/forum. Accessed 15 March 2012.

Seedhouse, P. 2004. The interactional architecture of the language classroom: A conversation analysis perspective. Oxford: Blackwell.

Singh, G, and J Richards. 2006. Teaching and learning in the language teacher education course room. Reg Lang Cent J 37: $37-46$.

Toohey, K, and B Waterstone. 2004. Negotiating expertise in an action research community. In Critical pedagogies and language learning, ed. B Norton and K Toohey, 111-123. Cambridge: Cambridge University Press.

Vygotsky, LS. 1978. Mind in society. Development of higher psychological processes. Harvard: Harvard University Press.

Wilhelm, KH. 1997. Sometimes kicking and screaming: language teachers-in-training react to a collaborative training model. Mod Lang J 81: 527-542.

Zapata, G. 2004. Second language instructors and CALL: a multidisciplinary research framework. Comput Assist Lang Learn 17: 339-356.

Zarate, G, D Lévy, and C Kramsch (eds.). 2008. Précis du plurilinguisme et du pluriculturalisme. Paris: Editions des archives contemporaines. 
Ziegler, G. 2008. De l'apprenant à l'acteur: les catégorisations dans l'interaction comme lieu d'acquisition. In Précis du plurilinguisme et du pluriculturalisme, ed. G Zarate et al., 39-42. Paris: Editions des archives contemporaines.

Ziegler, G (ed.). 2011a. Language teacher education in Europe. ForumSprache 5. http://www.ingentaconnect.com/ content/hueber/forum. Accessed 15 March 2012.

Ziegler, G. 2011b. Innovation in learning and development in multilingual and multicultural contexts: principles learned from a higher educational study programme in Luxembourg. Int Rev Educ 57: 685-703. doi:10.1007/ s11159-011-9252-6.

Ziegler, G, L Eskildsen, C Bottin, CM Coonan, and G Ludbrook. 2009a. Training teachers of languages in Europe. Analytical report. Sèvres: CIEP.

Ziegler, G, L Eskildsen, C Bottin, CM Coonan, and G Ludbrook. 2009b. Recommendations for optimising language teacher training in Europe. Sèvres: CIEP. http://www.semlang.eu/. Accessed 15 March 2012.

doi:10.1186/2191-5059-3-1

Cite this article as: Ziegler: Multilingualism and the language education landscape: challenges for teacher training in Europe. Multilingual Education 2013 3:1.

\section{Submit your manuscript to a SpringerOpen ${ }^{\circ}$ journal and benefit from:}

- Convenient online submission

- Rigorous peer review

- Immediate publication on acceptance

- Open access: articles freely available online

High visibility within the field

- Retaining the copyright to your article

Submit your next manuscript at $>$ springeropen.com 